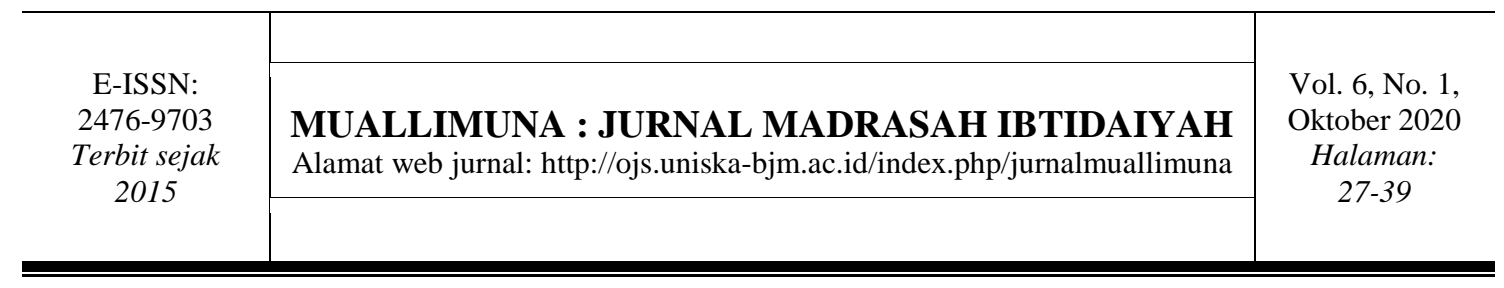

\title{
PENGEMBANGAN BUKU PENGAYAAN BERMUATAN LOKAL BAGI MAHASISWA PGSD
}

\author{
Rista Sundari $^{1}$, Tri Karyono ${ }^{2}$, Zakarias Sukarya Soeteja ${ }^{3}$ \\ ${ }^{1}$ PIAUD, Universitas Islam Negeri Walisongo \\ ${ }^{2,3}$ FSRD, Universitas Pendidikan Indonesia \\ ${ }^{1}$ rista.sundari@walisongo.ac.id, ${ }^{2}$ tri3karyono@gmail.com, ${ }^{3}$ Zakarias@upi.edu
}

\begin{abstract}
Abstrak: Pengembangan buku pengayaan bermuatan lokal ini didasarkan pada keterbatasan bahan ajar bermuatan lokal. Materi yang dijadikan bahan ajar bermuatan lokal merupakan produk budaya "Payung Geulis Kriya Tasikmalaya" sesuai dengan kebutuhan. Pengembangan buku pengayaan ini dimaksudkan agar memenuhi ketersediaan bahan ajar bermuatan lokal yang memberikan manfaat dan kemudahan dalam proses pembelajaran. Metode yang digunakan dalam penelitian ini menggunakan desain penelitian dan pengembangan $\mathrm{R} \& \mathrm{D}$ (Research and Development) bekerjasama dengan kriyawan dan para ahli yang kompeten. Materi yang terdapat pada isi buku pengayaan adalah latar belakang payung geulis Tasikmalaya, fungsi, alat dan bahan, proses pembuatan, motif hias serta proses dan teknik membuat motif hias. Hasil penelitian menunjukan bahwa buku pengayaan yang dihasilkan termasuk dalam kategori layak digunakan dan mampu dipahami dengan baik oleh mahasiswa PGSD.
\end{abstract}

Kata Kunci: buku pengayaan, pendidikan seni rupa, kearifan lokal

\section{THE DEVELOPMENT OF LOCAL WISDOM ENHANCEMENT BOOK FOR PGSD STUDENTS}

\begin{abstract}
The development of this local wisdom enrichment book is based on limited teaching materials. Materials that are used as teaching materials with local wisdom are cultural products "Payung Geulis Kriya Tasikmalaya" according to needs. The development of this enrichment book is intended to meet the availability of local wisdom teaching materials that provide benefits and convenience in the learning process. The method type used research and development design R\&D (Research and Development) in collaboration with competent craftsmen and experts. The material contained in the contents of the enrichment book is the background of the Payung Geulis Tasikmalaya, functions, tools and materials, the manufacturing process, decorative motifs, and the process and techniques for making decorative motifs. The results showed that the enrichment book produced was in the category of fit for use and was well understood by elementary school teacher education.
\end{abstract}

Keywords: enrichment books, fine art education, local wisdom 


\section{PENDAHULUAN}

Salah satu cara yang dapat dilakukan untuk mengembangkan diri adalah melalui proses pendidikan, baik itu pendidikan formal maupun pendidikan non formal. Pendidikan formal dilaksanakan secara berjenjang dari mulai pendidikan dasar, pendidikan menengah, sampai pendidikan tinggi. Proses pendidikan ini tidak terlepas dari ilmu pengetahuan yang dapat digali dari hasil penelitian, buku-buku dan sumber lainnya yang relevan. Pendidikan pada perguruan tinggi memberikan pengetahuan, pengalaman maupun praktik kepada mahasiswa agar menjadi pendidik yang ahli pada bidangnya masing-masing.

Pendidikan pada perguruan tinggi PGSD dituntut untuk dapat memperoleh calon guru sekolah dasar yang berkualitas, memiliki wawasan, cara pandang yang sesuai dengan tujuan pendidikan. Proses belajar mengajar diperguruan tinggi mengacu kepada RPS yang telah disesuaikan dengan kurikulum prodi perguruan tinggi. Dosen harus memahami dan mendalami materi agar dapat disampaikan secara tepat kepada mahasiswa, agar mahasiswanya kelak dapat praktik dilapangan secara tepat dan terarah. Proses pendidikan ini tidak terlepas dari perangkat pembelajaran yang harus dikuasai. Perangkat pembelajaran tersebut salah satunya adalah bahan ajar. Proses belajar dan mengajar tidak terlepas dari bahan ajar yang melibatkan pendidik dan peserta didik (Ramdani, Y, 2012). Pendidik dapat menggunakan bahan ajar sebagai sumber materi utama maupun sebagai materi tambahan. Bahan Ajar yang tepat tentunya dapat meningkatkan sumber daya manusia kearah yang lebih baik. Tujuan pembelajaran yang terumuskan dengan jelas serta terarah pada bahan ajar diharapkan dapat menciptkan suasana perkuliahan yang efektif dan efisien (Pribadi dan Sjarif, 2010, hlm. 120). Bahan ajar memiliki bentuk yang berbeda tergantung dengan kebutuhan, baik yang berbentuk tertulis maupun tidak tertulis. Bahan ajar yang tidak tertulis diantaranya berupa audio. Bentuk tertulis dari bahan ajar yaitu buku, lembar kerja, modul dan lainnya yang telah disusun menjadi satu kesatuan yang utuh.

Salah satu bahan ajar yang dapat digunakan dalam proses belajar mengajar yaitu buku pengayaan. Buku pengayaan termasuk kedalam buku nonteks pelajaran yang berisi materi pendukung, buku pengayaan terdiri dari buku pengayaan pengetahuan, buku pengayaan keterampilan dan buku pengayaan kepribadian (pusat perbukuan, dalam Kusumo dan Glena 2017: 3-9). Buku pengayaan dapat diperoleh dari beragam sumber yang disesuaikan dengan tujuan pembuatannya. "Buku pengayaan pengetahuan tidak hanya bermanfaat bagi masyarakat umum dan peserta didik" (Desnita, Fadilah dan Budi, 2016: 99). Begitu pula dengan buku pengayaan keterampilan dan buku pengayaan kepribadian, memberikan manfaat bagi masyarakat umum maupun peserta didik yang disesuaikan dengan kebutuhan masing-masing. Lubis, Desnita dan Permana, (2016: 54) mengemukakan bahwa "guru sebagai fasilitator memiliki kewajiban memfasilitasi proses pembelajaran, salah satunya adalah memfasilitasi siswa untuk membaca buku pengayaan". Materi yang terdapat dalam buku pengayaan sangat beragam tergantung dengan kebutuhan. Penyebaran buku pengayaan kepada para peserta didik ini diharapkan dapat meningkatkan pemahaman serta pembiasaan membaca bagi peserta didik. "Buku pengayaan dapat dijadikan sumber belajar mandiri peserta didik agar mereka bisa memperoleh ilmu pengetahuan yang lebih luas dan mendalam" (Suryani dan Atun, 2017: 48). Pengembangan buku pengayaan dapat diperoleh dari beragam referensi baik itu dari pengamatan langsung oleh peneliti atau sumber lainnya yang relevan dengan materi yang akan disajikan. Buku pengayaan ini 
dapat juga digunakan sebagai media untuk memperkenalkan, melestarikan serta mengembangkan budaya lokal.

Pendidikan yang memberikan kepedulian terhadap kekayaan budaya salah satunya adalah pendidikan seni. Kurikulum mata pelajaran kesenian memuat aspek konsepsi, apresiasi dan kreasi yang disusun sebagai suatu kesatuan rangkaian aktivitas seni yang harus dialami siswa dalam aktivitas berapresiasi dan berkreasi seni (Ardipal, 2006: 9). Berapresiasi dan berkreasi dalam berkarya seni merupakan satu kesatuan yang tidak terpisahkan. Garapan bidang seni lebih kepada rasa, peserta didik yang mencapai taraf apresiasi dan kreasi yang tinggi bisa menjadi anak yang kreatif, toleransi, percaya diri dan cerdas (Suharto, 2007: 4). Ragam pendidikian seni meliputi seni tari, seni musik, seni teater, seni drama serta seni rupa. Pendidikan seni tersebut memiliki fungsi dalam mengembangakan kemampuan diri peserta didik dalam berteori (mendalami teori), berkarya (melatih keterampilan). Peserta didik belajar supaya memiliki kemampuan dan kepribadian sesuai dengan kehidupan budaya masyarakatnya, bersumber dari kebudayaan yang merupakan kumpulan warisan sosial dalam masyarakatnya (Iriani, 2007: 53).

Pendidikan seni yang secara visual memiliki peranan dalam memelihara kebuadayaan adalah seni rupa. Pendidikan seni rupa terdiri dari teori dan praktik (apresiasi dan kreasi). Garha dan Idris (1980: 58) mengemukakan bahwa kegiatan apresiatif ialah "kegiatan penghayatan seni yang di dalamnya termasuk aktivitas mental yang berupa penikmatan, pengaguman serta penilaian". Kegiatan apresiasi yang memberikan pengalaman berkarya yaitu dengan cara praktik langsung membuat sebuah karya. Pelaksanaan praktik akan membuat peserta didik terbiasa dengan membuat sebuah kreasi karya seni. Teori-teori tentang proses kreasi dapat dikelompokkan menjadi dua yaitu teori yang didasari dengan aspek ketidaksadaran (ispirasi/ ilham, tidak dapat diprediksi) dan teori yang didasarkan pada kehendak atau kemauan sadar (dapat dilatih/ direkayasa) (Damajanti, 2006: 17). Setiap individu memiliki proses kreasi yang berbeda, bagi orang dewasa secara dominan dilakukan dengan penuh pertimbangan baik dan buruk, menarik atau tidak menarik dan lain-lain. Hal tersebut berbeda dengan proses kreasi anak, dalam berkreasi anak cenderung sepontan dan tidak banyak pertimbangan. "Aktivitas berkarya seni dilakukan melalui kegiatan eksplorasi dan eksperimen dalam mengolah gagasan (konsep), bentuk dan media (teknik) dengan mengambil unsur-unsur dari berbagai kegiatan individu maupun kelompok" (Yeni 2007: 20). Guru memiliki peranan untuk mengetahui kesenian didaerahnya guna untuk memperkenalkan kepada peserta didik, melestarikan bahkan mengembangkannya. Para pendidikan khususnya guru kesenian harus meningkatkan apresiasi seni masyarakat dalam sekolah maupun luar sekolah agar dapat meningkatkan kepekaan rasa, nilai-nilai keindahan, nilai moral dan etika, pemahaman serta penghargaan terhadap cipta seni (Ramanto, 2003: 161).

Kebudayaan yang merupakan warisan dalam masyarakat, dapat dijadikan sebagai pengembangan materi ajar yang disesuaikan dengan potensi daerah setempat. Salah satunya berupa karya seni rupa yang berasal dari produk budaya setempat. Pembuatan materi ajar diharapkan dapat dijadikan gambaran untuk membangun kebudayaan dan peradaban yang lebih baik sesuai dengan fungsi dari pendidikan. Sebagian produk budaya lokal bangsa Indonesia tetap dipertahankan, sebagian sudah mengalami transformasi mengikuti perkembangan jaman. Karakter serta nilai-nilai budaya yang terdapat didaerah dapat diapresiasi dan ditanamkan melalui keberadaan budaya lokal yang tercantum di dalam bahan ajar. 
Bahan ajar yang berisi muatan lokal masih sedikit ditemukan, sehingga para pendidik diharapkan dapat mengembangkannya. Penulis bahan ajar harus memiliki pengalaman, dapat meramu berbagai informasi, memiliki semangat, kerja keras serta memiliki pengetahuan yang luas agar tersusun secara optimal. Implementasi pengembangan materi pembelajaran mencakup tujuan dari kegiatan pembelajaran, proses pembelajaran, capaian dari sebuah kegiatan pembelajaran serta yang tidak kalah pentingnya yaitu media pembelajaran. Media pembelajaran dapat memberikan manfaat dalam proses belajar mengajar, membantu pendidik untuk menyampaikan pembelajaran lebih sederhana dan nyata sehingga mempermudah pemahaman siswa (Batubara, H.H, 2015). Hasil karya seni disetiap daerah yang beragam seperti alat tradisional, bangunan bersejarah artefak seni dan lain-lain dapat dijadikan sebagai insfirasi dalam membuat materi dalam buku pengayaan. Karya seni yang ada didaerah sebagian besar tidak ada penciptanya karena tidak ada unsur komersial maupun persaingan antar individu serta diwariskan secara turun temurun (Budiwirman, 2005: 63). Karya seni daerah tersebut, dapat dipelihara dikembangkan serta di dokumentasikan salah satunya dalam bentuk buku.

Berdasarkan uraian di atas, adanya keterbatasan bahan ajar yang bermuatan lokal membuat penulis merasa termotivasi untuk membuat sumber belajar tambahan yaitu buku pengayaan berbasis kearifan lokal. Pentingnya pendidik membuat bahan ajar atau mengembangkan pengetahuan serta mengetahui kesenian didaerahnya. Isi materi yang terdapat di dalam buku pengayaan disesuaikan dengan kebutuhan dalam proses pembelajaran PGSD di Universitas Perjuangan Tasikmalaya mata kuliah seni rupa. Materi budaya lokal untuk buku pengayaan yaitu "payung geulis kriya Tasikmalaya". Tujuannya agar mempermudah pemahaman materi dalam proses pembelajaran. Oleh karena itu, dalam penelitian ini penulis mengembangkan buku pengayaan bermuatan lokal sebagai bahan ajar bagi mahasiswa PGSD.

\section{METODE}

Metode penulisan yang digunakan dalam penelitian ini adalah metode $\mathrm{R} \& \mathrm{D}$ (research and Development). Menurut Emzir (2012: 268) "penulisan desain dan pengembangan mengarah pada produksi pengetahuan, suatu pemahaman yang lebih lengkap tentang lapangan dan kemampuan untuk membuat prediksi". Pemilihan metode penulisan ini dimanfaatkan untuk membuat sebuah buku pengayaan yang berisi uraian materi produk lokal (payung geulis kriya Tasikmalaya). Buku pengayaan ini diuji cobakan pada mahasiswa jurusan PGSD mata kuliah pendidikan seni rupa Universitas Perjuangan serta divalidasi oleh dosen yang kompeten dibidangnya. Penulisan ini memiliki beberapa tahapan berdasarkan dengan kebutuhan, melalui proses analisis serta uji coba pemahaman isi buku terhadap mahasiswa sehingga memiliki keefektifan produk yang dihasilkan.

Langkah-langkah penulisan dan pengembangan Borg \& Gall (dalam Emzir 2012). 1). penulisan dan pengumpulan informasi; 2). Perencanaan ; 3). Pengembangan bentuk awal produk; 4). Uji lapangan awal; 5). Revisi produk; 6). Uji lapangan utama; 7). revisi produk oprasional; 8). Ujian lapangan operasional; 9). Revisi produk akhir; 10). diseminasi dan implementasi. Pengambilan populasi ini didasarkan adanya matakuliah Pendidikan Seni Rupa pada mahasiswa PGSD smester 4 yang sesuai dengan kriteriakriteria kebutuhan penulisan serta kebutuhan lapangan. Materi mencakup pengetahuan mengenai budaya lokal Tasikmalaya yaitu mulai dari latar belakang payung geulis Tasikmalaya, alat dan bahan yang digunakan, prosedur pengerjaan meliputi: prosedur 
pembuatan payung geulis Tasikmalaya dan teknik pembuatan motif hiasnya. Teknik yang digunakan yaitu sampling purposive yang merupakan teknik penentuan sampel dengan pertimbangan tertentu (Sugiyono, 2012). Lokasi penelitian produk budaya lokal berada di kecamatan Indihiang Tasikmalaya yang merupakan tempat produksi payung geulis Tasikmalaya sebagai sumber penulis membuat bahan ajar. Uji coba bahan ajar dilakukan pada mahasiswa PGSD Universitas Perjuangan di Jln. Peta No. 177 Kota Tasikmalaya. Waktu uji coba disesuaikan dengan jadwal perkuliahan yang ditetapkan oleh pihak kampus.

Wawancara dilakukan berkaitan dengan kebutuhan yang dapat dijadikan materi buku pengayaan seni rupa. Selanjutnya penyusunan instrumen buku pengayaan yang penulis buat, divalidasi oleh ahli atau pakar sesuai dengan bidangnya. Instrumen uji pemahaman dan kelayakan buku dilakukan juga oleh mahasiswa dengan memberikan kuisioner (angket) berupa pernyataan tentang apresiasi dan kreasi mahasiswa. Indikator kelayakan buku pengayaan terdiri dari empat komponen penilaian yaitu komponen materi, komponen penyajian, komponen kebahasaan serta komponen kegrafikaan yang disesuaikan dengan indikator yang mendukung.

Tabel.1 Kriteria dalam bentuk persentase

\begin{tabular}{ccl}
\hline No & kriteria & \multicolumn{1}{c}{ Keterangan } \\
\hline 1. & $76 \%-100 \%$ & Sangat paham/ sangat jelas/ sangat lengkap/ sangat layak/ sangat menarik \\
2. & $51 \%-75 \%$ & Paham/ cukup jelas/ cukup lengkap/ cukup layak/ cukup menarik \\
3. & $26 \%-50 \%$ & Kurang paham/ kurang jelas/ kurang lengkap/ kurang layak/ kurang menarik. \\
4. & $0 \%-25 \%$ & Tidak paham/ tidak jelas/ tidak lengkap/tidak layak/ tidak menarik \\
\hline
\end{tabular}

Tabel.2 Kriteria persentase kecenderungan

\begin{tabular}{ccl}
\hline No & Kriteria & \multicolumn{1}{c}{ Keterangan } \\
\hline 1. & $51 \%-100 \%$ & Cenderung sangat paham/ paham \\
2. & $0 \%-50 \%$ & Cenderung tidak paham/ kurang paham \\
\hline
\end{tabular}

Penulis menggunakan teknik pengumpulan data diantaranya teknik pengamatan/ observasi langsung ke lapangan, wawancara dengan kriyawan serta mahasiswa, studi dokumen serta pengumpulan data dari sumber-sumber tertulis seperti buku, artikel maupun e-book. Dokumentasi dilakukan dalam bentuk tulisan, gambar, serta video. Prosedur pengembangan bahan ajar buku pengayaan ini dilakukan dengan beberapa tahapan yaitu melihat dari potensi dan masalah, mengumpulkan informasi, membuat desain produk, validasi desain, perbaikan desain, melakukan uji coba produk. Analisis data lakukan yaitu dengan analisis kualitatif dan kuantitatif. "Penulis metode campuran menggunakan teori sebagai kerangka kerja yang menginformasikan banyak aspek rancangan ketika penulis mengumpulkan, menganalisis, dan menginterpretasikan data kuantitatif dan kualitatif “(Creswell, 2017b: 100).

\section{HASIL DAN PEMBAHASAN \\ Hasil}

Produk akhir buku pengayaan berbasis kearifan lokal

1. Sampul depan, tengah dan belakang 


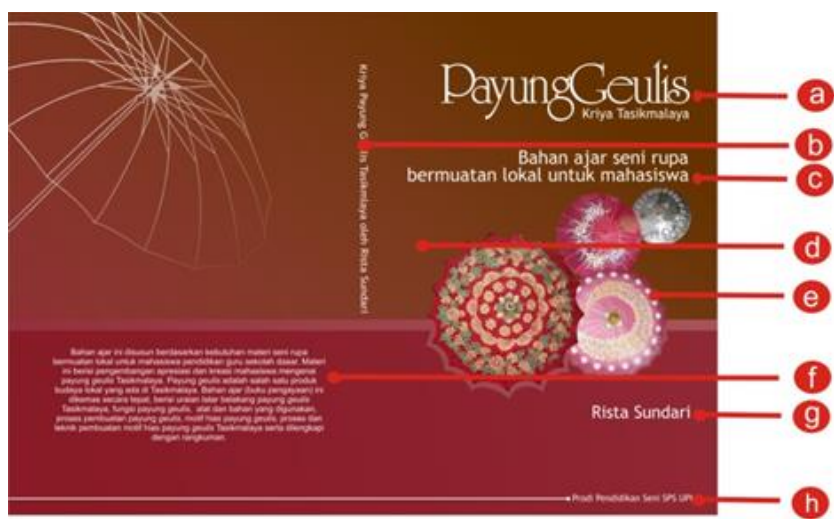

Gambar 1. Sampul depan, tengah dan belakang

Gambar tersebut merupakan keseluruhan dari cover buku pengayaan berbasis kearifan lokal. Adapun bagian-bagian yang terdapat pada sampul buku tersebut yaitu: a). judul buku; b). sampul bagian tengah buku yang terdiri dari judul buku serta nama penulis c). sub judul buku, yang merupakan pemaparan lebih spesifik dari judul buku; d). background atau latar belakang buku, merupakan satu kesatuan saling berkesinambungan antara background cover depan, tengah dan background bagian belakang cover buku; e). ilustrasi buku, terdiri dari ilustrasi payung secara utuh dan rangka payung; f). sinopsis buku yang merupakan ringkasan isi buku; g). nama penulis; h). penyelenggara buku pengayaan.

2. Backround

Background ini terletak pada seluruh isi dalam buku pengayaan setelah cover buku. Backround yang dibuat hanya berwarna putih polos tidak bermotif agar memperjelas gambar serta teks buku pengayaan.

3. Susunan halaman prancis

Susunan halaman prancis terdiri dari judul buku yang ditempatkan pada bagian atas, nama penulis, penelaah materi dan editor, setting cover, penyelenggara atau penerbit, nama penerbit buku.

4. Pengantar dari penulis

Pengantar dari penulis berisi pujian kehadirat alloh SWT, ucapan terimakasih, tujuan dari pembuatan bahan ajar serta dibubuhkannya bulan, tahun pengesahan serta nama asli dari penulis.

5. Daftar isi

Daftar isi berisi poin-poin materi yaitu; pengantar dari penulis; daftar isi; penulisan bahan ajar; pendahuluan; isi mencakup latar belakang, fungsi, alat dan bahan, proses pembuatan, motif hias payung, proses dan teknik pembuatan motif hias payung serta rangkuman; daftarpustaka; daftar istilah serta; biografi penulis.

6. Penulisan bahan ajar

Penulisan bahan ajar berisi pemaparan alasan dan tujuan dari pembuatan bahan ajar.

7. Pendahuluan

Pendahuluan berisi: perlunya pengembangan materi bagi tenaga pendidik; memaparkan beberapa produk budaya Tasikmalaya; cakupan materi yang disajikan serta ruang lingkup konsumen buku.

8. Latar belakang payung geulis Tasikmalaya

Berisi pemaparan secara lengkap mengenai latar belakang produksi payung geulis.

9. Fungsi payung geulis Tasikmalaya 
B. Fungsi Payung Geulis Tasikmalaya

Fungsi payung geuls pada jaman dahulu sebagal

dari pakaian para wanita, sebagai pengiring raja ata

pejabat, memayungi pengantin, sebagai hiasan pada

bangunan bak bagan interior maupun eksterior.

digunakan dalam acara-acara festival, media pelengkap

pertunjukan, seni lukis, sebagai hiasan pada sudu.

mata).

1). Sebagai penahan panas Mataha

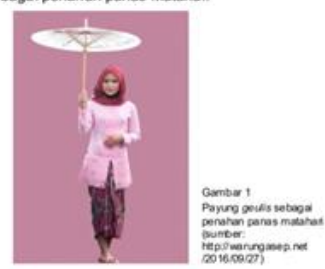

Pada awalinya fungsi payung gouls sebacai

(1)

Satriadi Y.P. (2013, him. 78) mengemukakan bahwa'

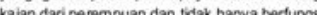

Gambar 2. Fungsi payung geulis Tasikmalaya

Pemaparan secara lengkap terkait dengan fungsi payung geulis Tasikmalaya.

10. Alat dan bahan payung geulis Tasikmalaya

Berisi pemaparan terkait dengan alat dan bahan pembuatan payung geulis Tasikmalaya.

11. Proses pembuatan payung geulis Tasikmalaya

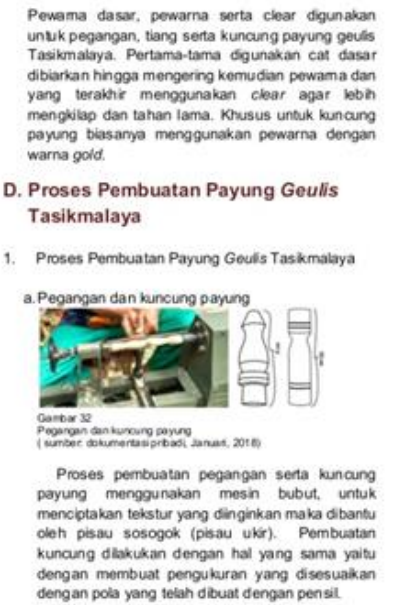

Gambar 3. Proses pembuatan payung geulis Tasikmalaya

Berisi pemaparan proses pembuatan payung geulis Tasikmalaya. 
12. Motif hias payung geulis Tasikmalaya

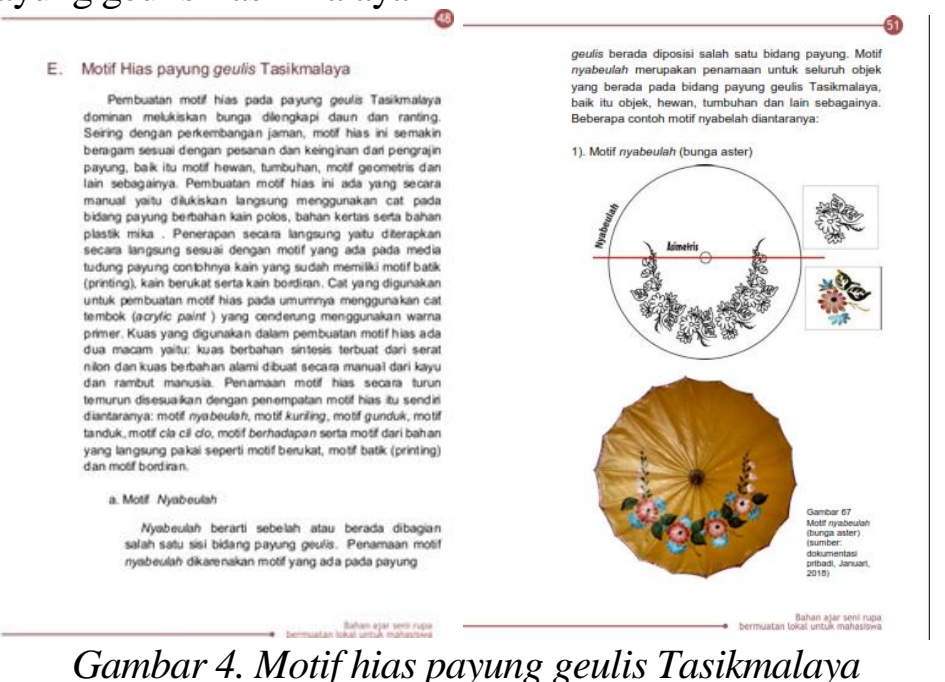

13. Pembuatan motif hias pada payung geulis Tasikmalaya

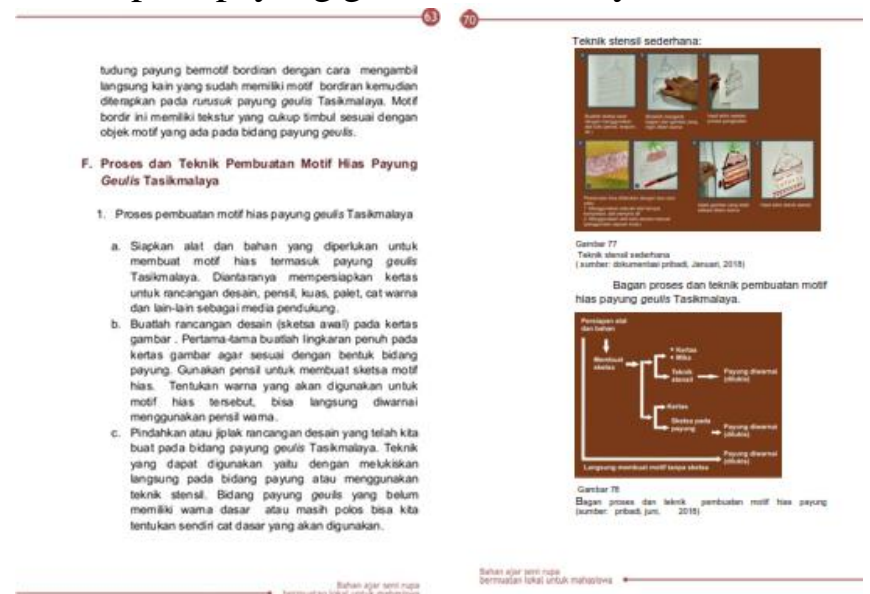

Gambar 5. Pembuatan motif hias pada payung geulis Tasikmalaya

Berisi pemaparan dalam membuat motif hias serta teknik pembuatannya. Pembuatan motif hias dapat dilakukan secara manual (dilukis) dan ada motif hias yang sudah ada dari bahan tudung payung itu sendiri. Motif hias yang sudah ada pada bahan tudung payung contohnya motif hias hasil bordir atau hasil printing dan lain-lainya. Selain terdapat teknik yang digunakan oleh para kriyawan, penulis menyisipkan teknik lain yang dapat digunakan untuk melukis payung geulis yaitu teknik stencil berikut dengan tahapan pembuatannya.

14. Rangkuman

Rangkuman berisi uraian singkat dari keseluruhan isi buku pengayaan.

15. Daftarpustaka

Daftar pustaka merupakan referensi pengambilan materi, pengambilan gambar baik itu secara langsung maupun tidak langsung.

16. Daftar Istilah

Daftar istilah berisi kata-kata yang sulit atau asing. Adanya daftar istilah memudahkan pembaca untuk memahami bacaan.

17. Biografi Penulis

Biografi penulis yang berisi riwayat pendidikan dari penulis. 


\section{Pembahasan}

Pembuatan buku pengayaan ini sebagai bahan ajar, dibuat berdasarkan kebutuhan mahasiswa PGSD. Hasil penelitian ini sejalan dengan beberapa hasil penelitian yang telah dilakukan sebelumnya, bahwa buku pengayaan sangat dibutuhkan dan menunjang tujuan pembelajaran. Buku pengayaan berbasis kearifan lokal dapat memperkuat karakter peserta didik berupa sikap cinta tanah air, memiliki rasa menghargai dan bangga terhadap budaya bangsa (Rediati, A, 2015, hal 2-3). Hasil penelitian lainnya bahwa bahan ajar dapat menjadi alat eksplorasi bagi peserta didik untuk memberikan inspirasi, mengembangkan kemampuan, kepekaan terhadap lingkungan (Astuti E. P dan Ismail, 2013, hal. 2) (Siska, Y, 2015, hlm. 209-210).

Buku pengayaan ini memberikan pemaparan "payung geulis kriya Tasikmalaya" yang merupakan salah satu produk budaya dari Tasikmalaya.

Tahapan-tahapan yang dilakukan penulis untuk menyusun buku pengayaan berbasis kearifan lokal yaitu sebagai berikut:

1. Analisis Kebutuhan Mahasiswa PGSD sesuai dengan RPS

Pengembangan buku pengayaan bermuatan lokal ini disesuaikan dengan kurikulum dan RPS. Bahan ajar ini dipergunakan oleh mahasiswa PGSD untuk mempermudah pemahaman materi. Mahasiswa memberikan apresiasi terhadap produk budaya lokal serta berkreasi dengan cara melukis motif hias pada media payung geulis Tasikmalaya. Buku pengayaan ini dapat dikategorikan sebagai buku pengayaan keterampilan karena penulis memfokuskan pada praktik membuat motif hias pada payung geulis Tasikmalaya.

2. Mengumpulkan materi secara langsung ke lapangan

Bahan ajar dibuat penulis dengan memahami latar belakang serta tujuan dari pembuatan bahan ajar. Penelitian ini dilakukan dengan cara mengamati langsung proses pembuatan dan melakukan wawancara kepada para kriyawan payung geulis serta studi literatur.

3. Menyusun materi bahan ajar

Penyusunan materi disesuaikan dengan kebutuhan terutama mengenai motif hias payung geulis Tasikmalaya yang akan dijadikan bahan praktik untuk mahasiswa. Materi yang disajikan untuk buku pengayaan yaitu latar belakang payung geulis Tasikmalaya, fungsi payung geulis Tasikmalaya, alat dan bahan payung geulis Tasikmalaya, proses pembuatan payung geulis Tasikmalaya, motif hias payung geulis Tasikmalaya, proses dan teknik pembuatan motif hias payung geulis Tasikmalaya serta dilengkapi dengan rangkuman.

4. Desain isi buku pengayaan

Sebelum adanya validasi atau saran dari para ahli, penulis menentukan ukuran buku sesuai standarisasi ISO dengan ukuran A5 (14,8x $21 \mathrm{~cm})$. Menggunakan jenis grid manuscript grid (grid 1 kolom), merupakan grid yang paling sederhana. Penggunaan tipografi ( La Bamba Let, Mister Earn BT dan Times New Roman) disesuaikan dengan bagian-bagian buku. Berikut penulis membuat sebuah rancangan buku pengayaan dengan menentukan komponen bahan ajar sebagai berikut:

5. Menentukan tampilan awal desain sampul (sampul depan, tengah dan belakang).

Desain sampul depan memuat judul buku, sub judul, nama penulis, nama penerbit, ilustrasi serta background. Desain sampul tengah terdiri dari Nama Penulis, judul buku dan penerbit. Desain sampul belakang buku pengayaan, terdapat synopsis isi materi, nama penerbit serta ilustrasi kerangka payung. Background sampul depan, tengah dan belakang memiliki kesatuan paduan yang selaras. 
6. Tampilan awal konten

Terdiri dari susunan halaman prancis, kata pengantar, daftar isi, susunan penulisan bahan ajar serta susunan pendahuluan. Pada halaman prancis terdiri dari nama judul, nama penulis, penelaah materi dan editor, setting cover serta nama penerbit.

7. Susunan isi atau konten materi produk budaya lokal payung geulis Tasikmalaya.

Penempatan susunan isi atau konten materi terdiri atas latar belakang payung geulis Tasikmalaya, alat dan bahan, proses pembuatan, motif hias, teknik membuat motif hias serta rangkuman.

8. Susunan akhir atau penutup terdiri atas susunan daftar pustaka, daftar istilah serta bioghrafi penulis.

Kelayakan materi apresiasi dan kreasi payung geulis sebagai bahan ajar buku pengayaan pendidikan seni rupa di PGSD

1. Proses validasi buku ajar berbasis kearifan lokal "Payung geulis kriya Tasikmalaya".

Proses validasi dilakukan oleh para ahli yang kompeten dalam bidangnya dari segi materi dilakukan dengan dosen ahli materi dan kriyawan payung geulis Tasikmalaya. Validasi komponen kegrafikaan dilakukan dengan dosen desain yaitu pak Arif Johari, M.Ds. Proses validasi dilakukan agar bahan ajar ini layak untuk beredar dengan cakupan yang luas. Tahap pertama validasi, penulis mendapatkan banyak masukan. Masukan atau perbaikan dari dosen ahli desain yaitu cover dan layout (pengunaan warna, background, komposisi, penempatan objek gambar, typografhi serta ilustrasi). Beberapa gambaran perbaikan yaitu penggunaan tyfografhi yang digunakan mengalami perubahan, pada awalnya "la bamba let" menjadi "adobe song std L" dengan modifikasi shape tool. Materi isi buku pengayaan menggunakan jenis arial. Perubahan pada backround, sebelum revisi terdapat bidang yang dominan lengkung berwarna coklat tua dan coklat muda, setelah adanya revisi berganti warna menjadi warna merah, terdapat warna merah muda dengan tambahan garis serta bentuk bayangan payung berwarna merah muda. Masukan dan saran perbaikan dari kriyawan meliputi prosedur pembuatan payung geulis Tasikmalaya. Prosedur pembuatan tersebut terdiri dari proses pemasangan pegangan payung pada bola-bola dan proses pemasangan kuncung payung. Revisi dilakukan penulis sesuai dengan hasil validasi. Setelah validasi dan revisi selesai, kemudian di uji coba kepada mahasiswa PGSD yang mengambil matakuliah seni rupa pada semester genap. Uji coba ini dilakukan pada 60 mahasiswa sesuai dengan kebutuhan dan pertimbangan penulis.

Langkah yang penulis ambil untuk menguji tingkat pemahaman mahasiswa terhadap buku pengayaan yaitu dengan cara:

a. Memberikan sejumlah soal yang telah disesuaikan dengan isi dari buku berupa lima soal pilihan ganda serta enam soal essay

b. Memberikan angket berupa pernyataan yang berisi pemahaman mahasiswa terhadap buku pengayaan "payung geulis kriya Tasikmalaya"

Pemberian sejumlah soal diharapkan agar mahasiswa dapat membaca isi buku dan dapat memahaminya. Total mahasiswa secara keseluruhan yaitu 60 orang. Sebanyak 37 mahasiswa memiliki nilai antara 100 sampai 98. Sebanyak 12 orang mahasiswa memiliki nilai antara 97-95. Sebanyak tujuh orang mahasiswa memiliki nilai antara 9492. Sebanyak dua orang memiliki nilai antara 91-89. Sebanyak satu orang memiliki nilai antara 88-86. Sebanyak satu orang mahasiswa memiliki nilai diantara 85-83 orang. Kelompok berinterval tersebut menggambarkan mahasiswa dominan memiliki nilai 
yang tinggi, sehingga mahasiswa tersebut cenderung dapat membaca secara keseluruhan sesuai dengan perimbangan soal yang telah penulis berikan.

Angket pernyataan berisi pemahaman mahasiswa terhadap buku pengayaan disertai dengan saran dan masukan dari mahasiswa. Hasil dari pemberian angket terhadap 60 orang memberikan dua jawaban yaitu sangat paham dan paham. Persentase rata-rata secara keseluruhan $75,35 \%$ yang memiliki arti buku pengayaan ini cenderung sangat dipahami/ paham.

2. Praktik membuat kreasi motif hias pada payung geulis Tasikmalaya

3. Pemberian angket penilaian buku pengayaan terhadap mahasiswa

Uji coba kedua yaitu melakukan praktik membuat motif hias pada payung geulis Tasikmalaya. Praktik dilakukan sesuai dengan langkah-langkah yang terdapat pada buku pengayaan sebagai berikut.

1. Mempersiapkan alat dan media lukis

2. Membuat sketsa awal

3. Memindahkan hasil sketsa atau rancangan desain

4. Membuat campuran warna

5. Mulai melukis (menggunakan teknik sapuan kuas)

6. Merapihkan hasil lukisan (detail)

Mahasiswa dibebaskan untuk membuat motif hias sesuai dengan kreasi masingmasing individu tetapi tetap dengan tema yang ditentukan. Hasil karya mahasiswa memiliki nilai yang beragam sesuai dengan kemamuan dan kreatifitas masing-masing individu. Proses membuat motif hias dilakukan dengan baik oleh mahasiswa sesuai dengan prosedur serta teknik yang terdapat di dalam buku pengayaan. Analisis dilakukan penulis pada langkah-langkah serta teknik pembuatan motif hias. Secara keseluruhan langkah-langkah dan teknik pembuatan motif hias dilakukan mahasiswa sesuai dengan langkah-langkah yang ada pada buku pengayaan. Sehingga buku pengayaan yang penulis buat bisa dijadikan salah satu referensi atau layak untuk digunakan oleh mahasiswa.

Rentang skor untuk angket yaitu satu sampai dengan empat meliputi komponen materi, penyajian, kebahasaan serta kegrafikaan. Penilaian mahasiswa terhadap buku pengayaan dengan perolehan persentse jumlah rata-rata secara keseluruhan yaitu $79,94 \%$. Oleh karena itu dapat ditarik kesimpulan penilaian mahasiswa terhadap buku pengayaan terletak pada kriteria $51 \%-100 \%$ dengan artian buku pengayaan ini cenderung sangat pahami/ paham. Setelah uji coba yang kedua, peneliti tidak melanjutkan proses perbaikan dan buku pengayaan (bahan ajar) berbasis kearifan lokal ini layak untuk digunakan sebagi buku pengayaan.

\section{PENUTUP}

Penulis membuat bahan ajar berupa buku pengayaan berdasarkan kebutuhan mahasiswa PGSD matakuliah seni rupa. Penulis melakukan dua tahapan dalam proses pembuatan buku pengayaan yaitu:

1. Pengembangan materi buku pengayaan sebagai bahan ajar

Penulis membuat buku pengayaan berbasis produk budaya lokal Tasikmalaya dengan judul "payung geulis kriya Tasikmalaya". Isi materi dalam buku pengayaan ini mencakup kriya payung geulis dan praktik membuat motif hias payung geulis Tasikmalaya.

2. Kelayakan materi apresiasi dan kreasi payung geulis Tasikmalaya

Buku pengayaan yang penulis buat melalui proses validasi dengan dosen ahli 
kriyawan serta mahasiswa. Buku pengayaan ini diperbaiki secara bertahap sesuai dengan kritik dan saran dari hasil validasi. Uji coba dilakukan terhadap 60 mahasiswa untuk mengetahui tingkat pemahaman dan kelayakan dari buku pengayaan. Berdasarkan hasil penelitian, bahan ajar berupa buku pengayaan ini layak untuk digunakan dan dapat di pahami dengan baik oleh mahasiswa PGSD.

\section{UCAPAN TERIMA KASIH}

Terimakasih kepada bapak Arif Johari, M.Ds selaku validator ahli desain. Terimakasih kepada bapak Nanang Ganda Prawira M.Sn, bapak Agus AW, M.Sn . Terimakasih kepada kriyawan yaitu bapak Budi Indra Praja dan bapak Nanang serta kepada semua pihak lainnya yang terlibat dalam pelaksanaan penelitian.

\section{DAFTAR PUSTAKA}

Ardipal. (2006). Peningkatan Apresiasi dan Kreasi Seni Vokal Siswa Sekolah Umum dengan Latihan Pembentukan Suara. 7(1), 114.

Astuti, E. P. (2013). Pengembangan Bahan Ajar Mata Kuliah Dasar-Dasar Desain Berbasis Kearifan Lokal Bagi Mahasiswa Pendidikan Seni Rupa. Imaji: Jurnal Seni dan Pendidikan Seni, 11(2).

Batubara, H. H. (2015). Pengembangan Media Pembelajaran Interaktif pada Materi Operasi Bilangan Bulat. MUALLIMUNA: Jurnal Madrasah Ibtidaiyah, 1(1), 112.

Budiwirman. (2005). Pendidikan Seni Tradisional dalam Seni Rupa Modern. 6 (2), 63.

Creswell, J. W (2017) Research Design Pendekatan Metode Kualitatif, kuantitatif dan Campuran, Yogyakarta. Pustaka Pelajar, 100.

Damajanti, I. (2006). Psikologi Seni. Bandung: PT Kiblat Buku Utama.

Desnita, D., Fadilah, N., \& Budi, E. (2016). Pengembangan Buku Pengayaan Kajian Fisis Peristiwa Angin Puting Beliung untuk Siswa SMA. Jurnal Penelitian \& Pengembangan Pendidikan Fisika, 2(2), 97-104.

Emzir. (2012). Metodologi Penelitian Pendidikan Kuantitatif \& Kualitatif. Jakarta: PT Rajagrafindo Persada.

Garha, O dan Idris, M. (1980). Seni Rupa Program Spesialisasi I. Jakarta. C.V. Angkasa.

Iriani, Z. (2007). Upaya Guru Memotivasi Siswa dalam Pembelajaran Seni Tari di Sekolah Dasar. 8(1),53.

Kusumo, Glena. (2018) Panduan Penyusunan Perangkat Pembelajaran dan Bahan Ajar 2017.http://docplayer.info/52565746-panduan-penyusunan-perangkatpembelajaran-bahan-ajar-2017.html

Lubis, M. A., Desnita, D., \& Permana, A. H. (2016, October). Pengembangan buku Pengayaan Pengetahuan Kajian fisis batubara untuk siswa SMA. In prosiding seminar nasional fisika (e-journal) (vol. 5, pp. Snf2016-rnd).

Pribadi, B. A., \& Sjarif, E. (2010). Pendekatan konstruktivistik dan pengembangan bahan ajar pada Sistem Pendidikan Jarak Jauh. Jurnal pendidikan terbuka dan jarak jauh, 11(2), 117-128.

Ramanto, M. (2003). Peran Guru Kesenian dalam Meningkatkan Apresiasi Seni Masyarakat. 4 (2), 161. 
Ramdani, Y. (2012). Pengembangan instrumen dan bahan ajar untuk meningkatkan kemampuan komunikasi, penalaran, dan koneksi matematis dalam konsep integral. Jurnal Penelitian Pendidikan, 13(1), 44-52.

Rediati, A. (2015). Pengembangan Buku Pengayaan Cara Menulis Teks Penjelasan Bermuatan Nilai Budaya Lokal untuk Peserta Didik Kelas V Sekolah Dasar. SELOKA: Jurnal Pendidikan Bahasa dan Sastra Indonesia, 4(1).

Siska, Y. (2015). Analisis Kebutuhan Bahan Ajar Sejarah Lokal Lampung Untuk Sekolah Dasar. Mimbar Sekolah Dasar, 2(2), 199-211.

Sugiyono. (2012). Metode Penelitian Kuantitatif Kualitatif dan R\&D. Bandung: Alfabeta.

Suharto, S. (2007). Pengembangan materi dan kegiatan pembelajarannya dalam kurikulum tingkat satuan pendidikan bidang seni musik. Harmonia: Journal Of Arts Research And Education, 8(3).

Suryani, A. S., \& Atun, S. (2017). Pengembangan Buku Pengayaan Kimia Reaksi Redoks dan Elektrokimia untuk SMA/MA Berdasarkan Kurikulum 2013. Jurnal Pembelajaran Kimia, 6(1), 47-54.

Yeni, I. (2007). Pembelajaran Apresiatif Seni Budaya (seni Musik) Menggunakan Kurikulum Tingkat Satuan Pendidikan (KTSP) di SMA Kota Padang. 8 (1), 18. 